\title{
Phe354Leu Polymorphism of $L K B 1$ Is a Potential Prognostic Factor for Cytogenetically Normal Acute Myeloid Leukemia
}

\author{
MING-YU YANG ${ }^{1,2}$, HUI-HUA HSIAO ${ }^{3,4}$, YI-CHANG LIU ${ }^{3,4}$, \\ CHENG-MING HSU ${ }^{1,5}$, SHENG-FUNG LIN ${ }^{3,4}$ and PAI-MEI LIN ${ }^{6}$ \\ ${ }^{1}$ Graduate Institute of Clinical Medical Sciences, College of Medicine, \\ Chang Gung University, Tao-Yuan, Taiwan, R.O.C.; \\ ${ }^{2}$ Departments of Otolaryngology, Kaohsiung Chang Gung Memorial Hospital, \\ Chang Gung University College of Medicine, Kaohsiung, Taiwan, R.O.C.; \\ ${ }^{3}$ Division of Hematology-Oncology, Department of Internal Medicine, \\ Kaohsiung Medical University Hospital, Kaohsiung, Taiwan, R.O.C.; \\ ${ }^{4}$ Faculty of Medicine, Kaohsiung Medical University, Kaohsiung, Taiwan, R.O.C.; \\ ${ }^{5}$ Department of Otolaryngology, Chiayi Chang Gung Memorial Hospital and \\ Chang Gung University College of Medicine, Chiayi, Taiwan, R.O.C.; \\ ${ }^{6}$ Department of Nursing, I-Shou University, Kaohsiung, Taiwan, R.O.C.
}

\begin{abstract}
Background/Aim: Liver kinase B1 (LKB1) is a major activator of the AMP-dependent kinase/mammalian target of rapamycin pathway. The prevalence and the specificity of LKBI gene mutation in acute myeloid leukemia (AML) have not been well established. This study aimed to examine mutation of LKB1 in AML and its clinical and pathological implications. Patients and Methods: Eighty-five patients newly diagnosed with cytogenetically normal AML were analyzed using polymerase chain reaction followed by direct sequencing. Results: A silent mutation $(837 C>T)$ of LKBI was detected in one patient and a pathogenic polymorphism Phe354Leu which diminishes LKB1 ability to maintain cell polarity was detected in six (7\%) patients. The Phe354Leu polymorphism occurred concurrently with mutations of nucleophosmin 1
\end{abstract}

This article is freely accessible online.

Correspondence to: Sheng-Fung Lin, Division of HematologyOncology, Department of Internal Medicine, Kaohsiung Medical University Hospital, Kaohsiung, Taiwan, R.O.C. Tel: +886 73121101 ext.7071, e-mail: shlin@cc.kmu.edu.tw or Cheng-Ming Hsu, Department of Otolaryngology, Chiayi Chang Gung Memorial Hospital, Chiayi, Taiwan, R.O.C. Tel: +886 53621000 ext. 2076, e-mail:scm0031@cgmh.org.tw or Pai-Mei Lin, Department of Nursing, I-Shou University, Kaohsiung, Taiwan, R.O.C. E-mail: paimei@isu.edu.tw

Key Words: Liver kinase B1, LKB1, acute myeloid leukemia, AML, Phe354Leu polymorphism, cytogenetically normal.
(NPM1), fms-related tyrosine kinase 3 (FLT3) and CCAAT/enhancer binding protein alpha (CEBPA), but not with metabolism-related genes, isocitrate dehydrogenase [nicotinamide adenine dinucleotide phosphate (+)]1 (IDH1) and IDH2. Patients with Phe354Leu polymorphism diagnosed at younger ages had a worse overall survival. Conclusion: LKB1 may be involved in the leukemogenesis and progression of cytogenetically normal AML.

Acute myeloid leukemia (AML) is a very heterogeneous group of leukemia types with diverse presentation and variable responsiveness to therapy (1). Karyotype abnormality represents an important prognostic parameter in AML $(2,3)$. Nevertheless, approximately $50 \%$ of all patients with AML have a normal karyotype and are currently categorized in the intermediate-risk group (1-3). This group is quite heterogeneous, and additional molecular markers for the discrimination between prognostically different subsets of patients is of increasing importance (4). In recent years, several novel molecular markers have been identified that are important for prognostic relevance of patients with AML with normal karyotype $(5,6)$.

The tumor-suppressor gene liver kinase B1 ( $L K B 1)$, also known as STK11, is located on chromosome 19p13.3 (7). It consists of 11 coding exons and encodes a protein of 436 amino acids with a serine/threonine kinase, and possesses two nuclear localization signals in the $\mathrm{N}$-terminal region, a central catalytic kinase domain and a $C$-terminal putative farnesylation motif (8). The $L K B 1$ gene is ubiquitously expressed at varying levels in all fetal and adult tissues, with 
notably higher expression in the pancreas, liver, testes and skeletal muscle (9).

In complex with two other proteins, the STe20-related adapter (STRAD) pseudokinase and the scaffolding protein mouse protein 25 (MO25) (10), LKB1 has been shown to regulate cell-cycle arrest, apoptosis, autophagia and cellular energy metabolism, as well as cell polarity (11-14). LKB1 activates adenosine monophosphate (AMP)-activated protein kinase (AMPK) and other members of the AMPK family (15). The LKB1/AMPK pathway serves as the cellular energy sensor, allosterically activated under low cellular energy conditions by the accumulation of AMP molecules. Activation of AMPK stimulates catabolic pathway such as glycolysis and blocks anabolic pathways such as gluconeogenesis and lipogenesis, and controls protein synthesis though inhibition of the mammalian target of rapamycin (mTOR). The LKB1/AMPK pathway blocks cell growth under low nutrient conditions, and therefore is considered a tumor-suppressor pathway (16).

Germline mutations of the $L K B 1$ gene are responsible for Peutz-Jeghers syndrome, which is an autosomal dominant disorder characterized by hyperpigmentation and multiple benign gastrointestinal hamartomatous polyps. Patients with Peutz-Jeghers syndrome have an increased risk of gastrointestinal and several other types of cancer, including of the pancreas, lung, breast, uterus, cervix, testis and ovary (17). Somatic mutations of the $L K B 1$ gene have also been found in multiple sporadic cancer of the lung, pancreas, ovary, cervical and testis $(18,19)$. Mice with a heterozygous deletion of $L \mathrm{kbl}$ are tumor prone, showing an increased incidence of the development of cancer as well as increased susceptibility to carcinogen-induced tumorigenesis (20). Deletion or mutation of the $L K B 1$ gene is associated with a reduced progression-free survival in patients with cervical cancer (21). These observations further indicate a critical role of $L K B 1$ in tumorigenesis and progression.

Several recent studies show that loss of $L k b l$ in adult mice leads to loss of hematopoietic stem cell (HSC) quiescence, resulting in depletion of the HSC pool and a marked reduction of HSC repopulating potential in vivo. LKB1deficient HSCs and bone marrow cell exhibit reduced mitochondrial membrane potential and depletion of cellular ATP. These data define an essential role of the $L K B 1$ in restricting $\mathrm{HSC}$ entry into the cell cycle and in maintaining energy homeostasis through AMPK-dependent and AMPKindependent mechanisms (22-24). Moreover, several studies showed that the anti-diabetic drug metaformin (an LKB1/AMPK activator) exerted significant anti-leukemia cell activity in AML and T-cell acute lymphoblastic leukemia cells through inhibiting mTOR activity $(25,26)$. These studies demonstrated that the LKB1/AMPK tumor-suppressor axis is generally functional in hematopoietic cancer and that pharmacological intervention activating this pathway may represent a new target in anticancer therapy $(25,26)$.
In contrast to the expanding research field on $L K B 1$ in solid tumors, the biological and clinical implications of LKB1 gene alterations in hematological cancers have not been well established. Therefore, we investigated the prevalence and the clinical prognostic significance of $L K B I$ mutations in patients with newly-diagnosed AML to explore the potential of the LKB1/AMPK signaling pathway as a new target for anticancer drug development of hematologic malignancy.

\section{Materials and Methods}

Patient samples. Diagnostic bone marrow samples from 85 de novo adult patients with cytogenetically normal (CN) AML were collected at Kaohsiung Medical University Hospital. Complete remission was defined as the presence of fewer than $5 \%$ blasts cells in the bone marrow aspirate examination and evidence of normal maturation of other marrow elements after the first or second course of induction therapy. Only patients with fully regenerated peripheral blood counts (neutrophil recovery to $1.0 \times 10^{9} / 1$ and platelets to $100 \times 10^{9} / 1$ ) after induction therapy were included. This study was approved by the Institute Review Board of the Kaohsiung Medical University Hospital (IRB no. KMUH-IRB-990483), and bone marrow samples were obtained with informed consent. Screening of additional molecular markers associated with cytogenetically normal AML, namely fms-related tyrosine kinase 3 (FLT3) internal tandem duplication (FLT3-ITD), FLT3 tyrosine kinase domain (FLT3-TKD) mutation, nucleophosmin 1 (NPM1) mutation, CCAAT/enhancer binding protein alpha (CEBPA) mutation, isocitrate dehydrogenase $1(I D H 1)$ and $I D H 2$ were conducted as described previously (27-31).

RNA and DNA extraction. Total RNA was purified from mononuclear cells using TRIzol reagent (Invitrogen, Carlsbad, CA, USA) according to the manufacturer's protocols. Genomic DNA was extracted from mononuclear cell preparations using Illustrated $^{\mathrm{TM}}$ blood genomicPrep Mini Spin Kit (GE Healthcare UK Limited, Little Chalfont, Buckinghamshire, UK) according to the manufacturer's recommendations.

Analysis of LKB1 mutations. To detect the presence of LKB1 mutation, reverse transcription-polymerase chain reaction (RT-PCR) was performed as published previously (32). cDNA was synthesized from $2 \mu \mathrm{g}$ of total RNA using High Capacity cDNA Reverse Transcription Kit (Applied Biosystems, Foster City, CA, USA). The cDNA sequence of the $L K B 1$ gene was obtained from GenBank [GenBank: NM_000455]. The nine exons of LKB1 gene were divided into three sections and each section was amplified with primers as listed in Table I. PCR was carried out in a $25-\mu$ l final volume containing approximately $1 \mu \mathrm{lDNA}, 200 \mathrm{nM}$ of each primers, $200 \mu \mathrm{M}$ dNTPs, $1.5 \mathrm{mM} \mathrm{MgCl} 2,1.25 \mathrm{U}_{\text {GoTaq }}{ }^{\circledR}$ Flexi DNA Polymerase (Promega, Madison, WI, USA), and supplied buffer. PCR amplification consisted of initial denaturation at $95^{\circ} \mathrm{C}$ for $2 \mathrm{~min}$ followed by 35 cycles of $95^{\circ} \mathrm{C}$ for $40 \mathrm{sec}, 62^{\circ} \mathrm{C}$ for $40 \mathrm{sec}$, and $72^{\circ} \mathrm{C}$ for $1 \mathrm{~min}$ prior to a final elongation process at $72^{\circ} \mathrm{C}$ for 5 min. The PCR products were purified with a QIAquick PCRpurification kit (Qiagen, Hilden, Germany) and cycle-sequenced using the BigDye Terminator Cycle Sequencing Kit (Applied Biosystems). Sequencing was performed on an ABI PRISM 310 
Yang et al: LKB1 Phe354Leu Polymorphism as a Prognostic Factor for Cytogenetically Normal AML

Table I. Oligonucleotide primers for reverse transcriptase-polymerase chain reaction analysis of the liver kinase B1 (LKB1) gene (GenBank accession number NM_000455).

\begin{tabular}{lccc}
\hline Primer name & Amplicon size (bp) & Sequence & Primer location \\
\hline Exons 1-3 & 585 & F: 5'-AGT CGG AAC ACA AGG AAG GAC-3' & $1041-1061$ \\
& & R: 5'-CTG GCT ATG CAG GTA CTC CAG-3' & $1605-1625$ \\
Exons 4-7 & 502 & F: 5'-GAG AAG CGT TTC CCA GTG TG-3' & $1548-1567$ \\
& & R: 5'-CTT CAG CCG GAG GAT GTT T-3' & $2021-2049$ \\
Exons 8-9 & 519 & F: 5'-GAA AGG GAT GCT TGA GTA CGA A-3' & $1973-1994$ \\
& & R: 5'-AAC CGG CAG GAA GAC TGA G-3' & $2473-2491$ \\
\hline
\end{tabular}

F: Forward primer; R: reverse primer.

sequence apparatus (Applied Biosystems). Specimens with $L K B 1$ mutation were further confirmed with DNA samples.

Analysis of LKB1 Phe354Leu polymorphism. To detect the presence of $L K B 1$ Phe354Leu polymorphism, genomic DNA was used for $L K B 1$ exon 8 amplification with primers as follows: forward: 5'GAG CTG GGT CGG AAA ACT G-3'and reverse: 5'- AGA AGC TGT CCT TGT TGC AGA-3'. PCR was carried out in a $25-\mu$ f final volume containing approximately $100 \mathrm{ng}$ genomic DNA, $200 \mathrm{nM}$ of each primers, $200 \mu \mathrm{M}$ dNTPs, $1.5 \mathrm{mM} \mathrm{MgCl}_{2}, 1.25 \mathrm{U} \mathrm{GoTaq}^{\circledR}$ Flexi DNA Polymerase (Promega), and supplied buffer. PCR amplification consisted of initial denaturation at $95^{\circ} \mathrm{C}$ for $5 \mathrm{~min}$ followed by 35 cycles of $95^{\circ} \mathrm{C}$ for $30 \mathrm{sec}, 62^{\circ} \mathrm{C}$ for $30 \mathrm{sec}$, and $72^{\circ} \mathrm{C}$ for $30 \mathrm{sec}$ prior to a final elongation process at $72^{\circ} \mathrm{C}$ for $5 \mathrm{~min}$. Sequence analysis was performed as for analysis using cDNA samples.

Statistical analysis. All statistical analyses were performed using SPSS software package, version 14 (SPSS, Chicago, IL, USA). Overall survival probabilities were calculated by Kaplan-Meier method, and differences in survival distribution were compared by the log-rank test. Overall survival was calculated from the date of first diagnosis to the date of last follow-up or death from any cause. Values of $p<0.05$ were considered statistically significant.

\section{Results}

Patient population. A total of 85 patients with de novo AML were included in this study (49 men and 36 women), aged 21-86 years (median age $=52.3$ years). In the entire patient population, the complete remission rate was $51.8 \%$ and the mean overall survival was 648 days. Molecular markers were also analyzed for all available diagnostic bone marrow samples. Mutant NPM1 was observed in 37 out of 85 patients $(43.5 \%)$, FLT3-ITD in 20/85 (23.5\%), FLT3-TKD in $7 / 85(8.2 \%)$, mutant $C E B P A$ in $32 / 85(37.6 \%)$, mutant IDH1 in $3 / 85(3.5 \%)$ and mutant $I D H 2$ in $11 / 85(12.9 \%)$. At least one molecular maker mutation was identified in $69 / 85$ $(81 \%)$ patients. Mutant FLT3 was more frequently associated with the presence of mutant NPM1 $(p<0.001)$. The presence of mutation of FLT3 led to significantly worse overall survival $(p<0.01)$. Clinical characteristics and the frequencies of the molecular marker of the 85 patients with de novo $\mathrm{CN}$ AML at the time of the initial diagnostic evaluation are summarized in Table II.

LKB1 gene mutations in patients with de novo CN AML. Here we reported our results about the mutation status of LKB1 in patients with de novo $\mathrm{CN}$ AML. One silent mutation $(837 \mathrm{C}>\mathrm{T})$ of $L K B 1$ was detected in a 22-year-old male patient who also had CEBPA mutation. This is in agreement with previous reports that $L K B 1$ mutations were relatively rare in patients with cancer who did not have Peutz-Jeghers syndrome, except for non-small cell lung cancers (NSCLCs) $(18,19)$. In addition, another alteration, Phe to Leu at codon 354 (Phe354Leu), was detected in $7 \%$ (6 out of 85) of our patients with AML (Figure 1). Phe354Leu was reported to be a rare polymorphism, the same mutation has been found in Koreans with left-sided colorectal cancer (in 6.3\%) as well as in cancer-free controls (in $5.6 \%$ ) from the same population (33). This mutation was found in one Peutz-Jeghers syndrome family including many affected relatives and the change seems to co-segregate with the disease (34).

Clinical characteristics and outcome of patients with AML with LKB1 Phe354Leu polymorphism. In this study, we found all six patients with the $L K B 1$ Phe354Leu polymorphism achieved complete remission after treatment. Among the six patients with Phe354Leu polymorphism, four of them were diagnosed at 31-36 years of age which was younger than the average age of whole patient group at diagnosis (52.3 years). Except one patient who had long overall survival $(1,786$ days), the other five patients had an average overall survival of 305 days (range $=106-452$ days), which is shorter than the overall survival of patients with AML overall (648 days). Concurrent mutations of other molecular markers, NPM1, FLT3, and CEBPA, were detected in all patients with $L K B 1$ Phe354Leu polymorphism. Three patients with LKBI 
in vivo $31: 841-847(2017)$

Table II. Clinical characteristics of patients with cytogenetically normal acute myeloid leukemia.

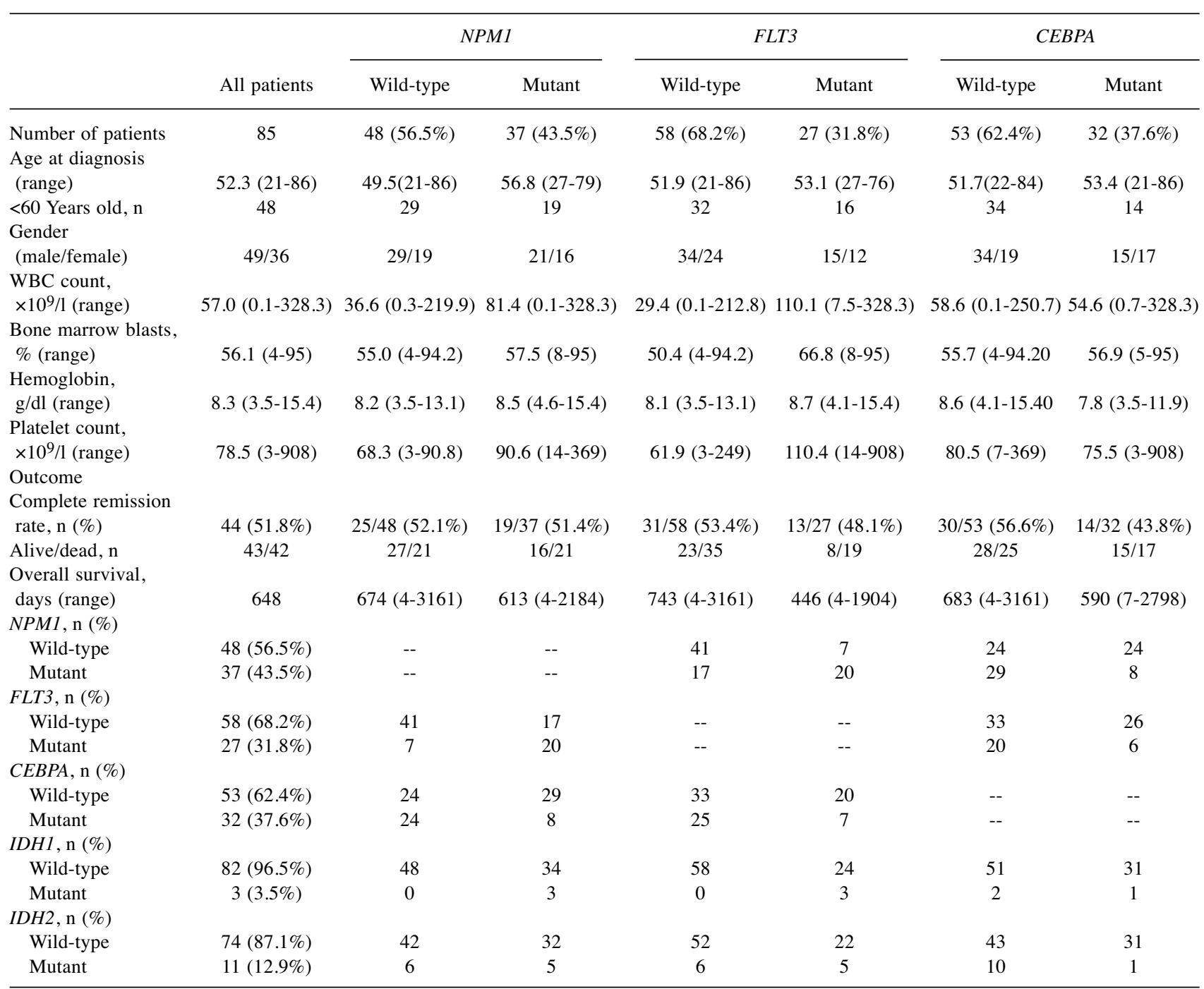

CEBPA: CCAAT/enhancer binding protein alpha; FLT3: fms-related tyrosine kinase 3; IDH1/2: isocitrate dehydrogenase [nicotinamide adenine dinucleotide phosphate $(+)] 1 / 2 ; N P M 1$ : nucleophosmin 1; WBC: white blood cell.

Phe354Leu polymorphism had NPM1 mutation, three patients had FLT3 mutation and four patients had CEBPA mutation. None of the patients had IDHI and IDH2 mutations. Compared to the overall survival of patients with NPM1 mutation only (613 days), the overall survival of the three patients with both LKBI Phe354Leu polymorphism and NPM1 mutation was shorter (322 days). Compared to the overall survival of patients with FLT3 mutation only (446 days), the overall survival of the three patients with both LKB1 Phe354Leu polymorphism and FLT3 mutation was also shorter (186, 106 and 377 days, respectively). Except for one patient with both LKB1 Phe354Leu polymorphism and $C E B P A$ mutation who was diagnosed at older age (69 years) and had longer overall survival (1,786 days), the overall survival of the other three patients with both LKB1 Phe354Leu polymorphism and CEBPA mutation (411 days) was shorter than the overall survival of the patients carrying only the CEBPA mutation (590 days). The clinical characteristics of the patients carrying the LKB1 Phe354Leu polymorphism are listed in Table III.

\section{Discussion}

It has long been known that tumor cells undertake aerobic glycolysis, the so-called Warburg effect. The alteration of the function of metabolic enzymes might help resolve the 


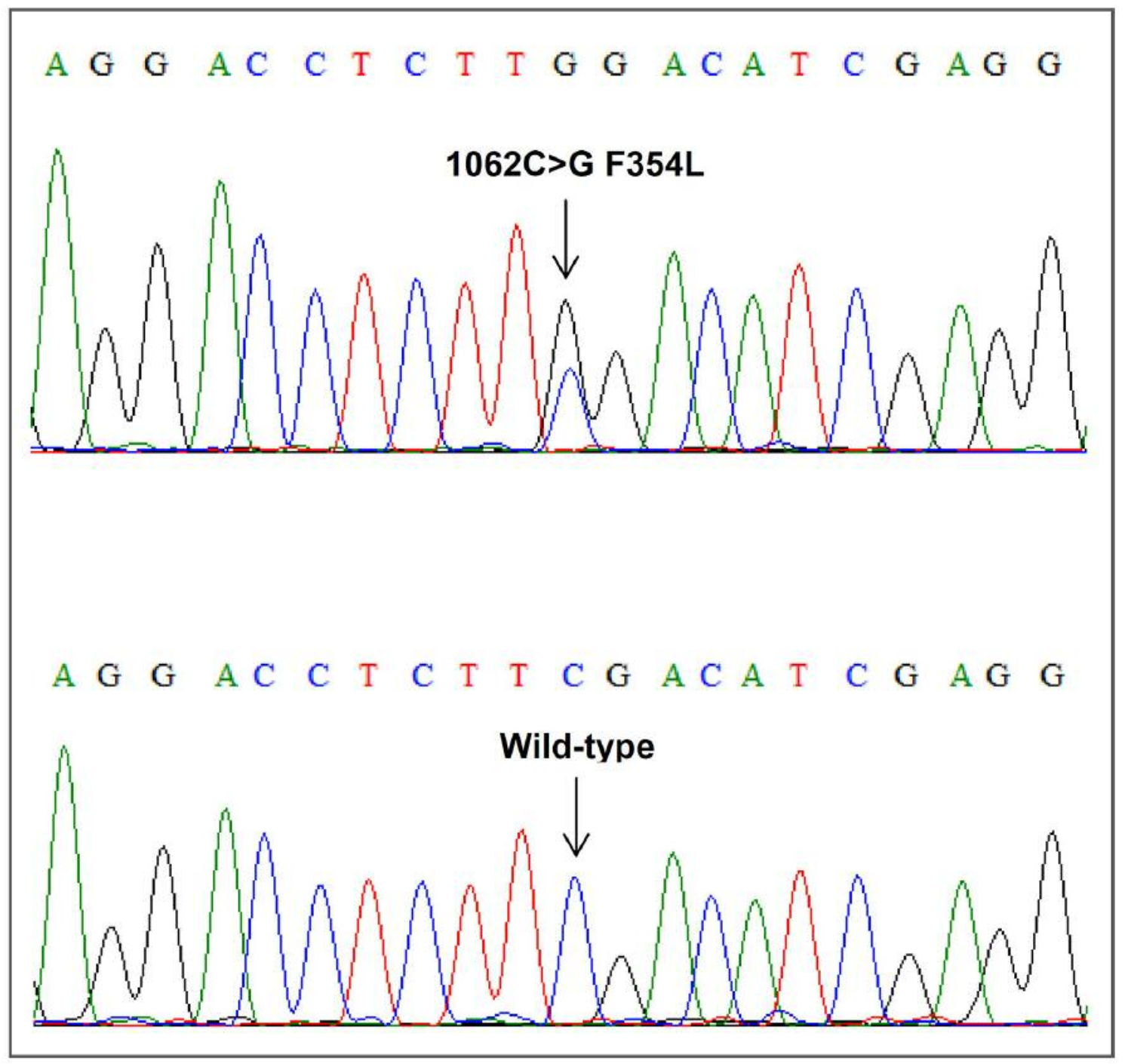

Figure 1. Sequence analysis of liver kinase B1 (LKB1) mutation. Reverse transcriptase-polymerase chain reaction amplification of cDNA and DNA from patients with acute myeloid leukemia revealed the 1062C $>G$ mutation, which leads to Phe354Leu change in the protein.

Table III. The clinical characteristic of patients with acute myeloid leukemia with liver kinase B1 (LKB1) Phe354Leu polymorphism.

\begin{tabular}{lccccccccc}
\hline $\begin{array}{l}\text { Patient } \\
\text { number }\end{array}$ & Gender & $\begin{array}{c}\text { Age at } \\
\text { diagnosis } \\
\text { (years) }\end{array}$ & $\begin{array}{c}\text { FAB } \\
\text { classification }\end{array}$ & $\begin{array}{c}\text { Survival } \\
\text { (days)/ } \\
\text { status }\end{array}$ & $\begin{array}{c}\text { WBC } \\
\text { count } \\
\left(\times 10^{9} / \mathrm{l}\right)\end{array}$ & $\begin{array}{c}\text { Bone } \\
\text { marrow } \\
\text { blast }(\%)\end{array}$ & $\begin{array}{c}\text { Hemoglobin } \\
(\mathrm{g} / \mathrm{d})\end{array}$ & $\begin{array}{c}\text { Platelet } \\
\text { count } \\
\left(\times 10^{9} / \mathrm{l}\right)\end{array}$ & $\begin{array}{c}\text { Other } \\
\text { molecular } \\
\text { markers }\end{array}$ \\
\hline 1 & Male & 69 & M2 & $1786 /$ alive & 29.56 & 35.2 & 8.7 & 4 & CEBPA mutation \\
2 & Male & 33 & M4 & $186 /$ dead & 64.76 & 69.4 & 9.9 & 58 & NPM1, FLT3 mutation \\
3 & Male & 54 & M2 & $106 /$ dead & 43.31 & 93.5 & 5.3 & 20 & FLT3 mutation \\
4 & Female & 36 & M1 & $452 /$ dead & 39.00 & 51.1 & 8.8 & 4 & CEBPA mutation \\
5 & Female & 34 & M4 & $403 /$ dead & 15.58 & 29.5 & 6.6 & 62 & NPM1, CEBPA mutation \\
6 & Female & 31 & M4 & $377 /$ dead & 100.71 & 8.3 & 7.7 & 120 & NPM1, FLT3, CEBPA mutation \\
\hline
\end{tabular}

FAB: French-American-British classification; CEBPA: CCAAT/enhancer binding protein alpha; FLT3: fms-related tyrosine kinase 3; NPM1: nucleophosmin 1; WBC: white blood cell. 
enigmatic, aerobic glycolytic state of cancer cells (35). For example, two metabolism-related genes, $I D H 1$ and $I D H 2$, are frequently mutated in different cancer types including $\mathrm{CN}$ AML (36, 37). Recently, the molecular characterization of the LKB1/AMPK signaling pathway as a tumor-suppressor axis further supports the link between cancer and metabolism (16). Studies on HSC and leukemia cells have also emphasized the potential value of LKB1/AMPK modulation in hematological malignancies (22-26).

Here we reported our results on the mutation status of $L K B 1$ in patients with de novo CN AML. We only found one silent mutation $(837 \mathrm{C}>\mathrm{T})$ in our AML specimens. This is in agreement with previous reports that $L K B 1$ gene mutations were found to be relatively rare in cancer from patients without Peutz-Jeghers syndrome except for non-small cell lung cancer (NSCLC) $(18,19)$. In addition, previous reports have suggested the $L K B 1$ mutations were infrequent in patients of Asian origin with NSCLC (3\%) compared to those found in NSCLC tumors and cell lines derived from patients of Caucasian origin (30\%) $(32,38)$. The difference in $L K B 1$ mutation frequencies between these two populations might be related to cigarette smoking history. These observations also indicate the possibility that $L K B 1$ alterations might be induced by ethnic and lifestyle or environmental factors $(32,39)$.

LKB1 Phe354Leu polymorphism was observed in $7 \%$ (6 out of 85) of our CN-AML patients. This polymorphism occurs in the $C$-terminal region of LKB1 rather than in the kinase domain. In a study by Forcet et al., the Phe354Leu alteration lessened LKB1-mediated activation of the AMPK and impaired downstream signaling, and diminish LKB1 ability to maintain the polarity of cells (40). Moreover, this mutation was found in one Peutz-Jeghers syndrome family including many affected relatives and the change seems to co-segregate with the disease (34). Results of these studies suggested Phe354Leu alteration is associated with cancer predisposition. In our study, the patients with AML with LKB1 Phe354Leu polymorphism were diagnosed at younger ages and had worse overall survival. LKBI Phe354Leu polymorphism also occurred concurrently with NPM1, FLT3, and CEBPA mutations. The concurrent LKB1 Phe354Leu polymorphism in patients with CN-AML seems to have a worse impact on the overall survival.

Our results indicate that $L K B 1$ Phe354Leu polymorphism may play an important role in leukemogenesis and represents a poor prognostic factor. Additional studies are needed to clarify the clinical implication of $L K B 1$ mutations in leukemia and whether $L K B 1$ mutations occur concurrently with other molecular makers and have mutual impact on prognosis.

\section{Acknowledgements}

This study was supported in part by grants from Chang Gung Memorial Hospital (grant numbers CMRPD8D0292, and
CMRPD8F0761) and Kaohsiung Medical University Hospital (grant numbers KMUH102-2T03, KMUH103-3R12, KMUH104-4R12, and 102-20).

\section{References}

1 Fröhling S, Scholl C, Gilliland DG and Levine RL: Genetics of myeloid malignancies: pathogenetic and clinical implications. J Clin Oncol 23: 6285-6295, 2005.

2 Grimwade D, Walker H, Oliver F, Wheatley K, Harrison C, Harrison G, Rees J, Hann I, Stevens R, Burnett A and Goldstone A: The importance of diagnostic cytogenetics on outcome in AML: analysis of 1,612 patients entered into the MRC AML 10 trial. Blood 92: 2322-2333, 1998.

3 Mrózek K, Heerema NA and Bloomfield CD: Cytogenetics in acute leukemia. Blood reviews 18: 115-136, 2004.

4 Estey E and Döhner H: Acute myeloid leukaemia. Lancet 368: 1894-1907, 2006.

5 Wang M, Yang C, Zhang L and Schaar DG: Molecular mutations and their cooccurrences in cytogenetically normal acute myeloid leukemia. Stem Cells Int 2017: 6962379, 2017.

6 Gregory TK, Wald D, Chen Y, Vermaat JM, Xiong Y and Tse W: Molecular prognostic markers for adult acute myeloid leukemia with normal cytogenetics. J Hematol Oncol 2: 23, 2009.

7 Hemminki A, Tomlinson I, Markie D, Järvinen H, Sistonen P, Björkqvist AM, Knuutila S, Salovaara R, Bodmer W, Shibata D, de la Chapelle A and Aaltonen LA: Localization of a susceptibility locus for Peutz-Jeghers syndrome to 19p using comparative genomic hybridization and targeted linkage analysis. Nat Genet 15(1): 87-90, 1997.

8 Alessi DR, Sakamoto K and Bayascas JR: LKB1-dependent signaling pathways. Annu Rev Biochem 75: 137-163, 2006.

9 Rowan A, Churchman M, Jefferey R, Hanby A, Poulsom R and Tomlinson I: In situ analysis of LKB1/STK11 mRNA expression in human normal tissues and tumours. J Pathol 192: 203-206, 2000.

10 Boudeau J, Baas AF, Deak M, Morrice NA, Kieloch A, Schutkowski M, Prescott AR, Clevers HC and Alessi DR: MO25alpha/beta interact with STRADalpha/beta enhancing their ability to bind, activate and localize LKB1 in the cytoplasm. EMBO J 22: 5102-5114, 2003.

11 Tiainen M, Vaahtomeri K, Ylikorkala A and Makela TP: Growth arrest by the LKB1 tumor suppressor: induction of $p 21$ (WAF1/CIP1). Hum Mol Genet 11: 1497-1504, 2002.

12 Liang J, Shao SH, Xu ZX, Hennessy B, Ding Z, Larrea M, Kondo S, Dumont DJ, Gutterman JU, Walker CL, Slingerland JM and Mills GB: The energy-sensing LKB1-AMPK pathway regulates $\mathrm{p} 27$ (KIP1) phosphorylation mediating the decision to enter autophagy or apoptosis. Nat Cell Biol 9(2): 218-224, 2007.

13 Faubert B, Vincent EE, Griss T, Samborska B, Izreig S, Svensson RU, Mamer OA, Avizonis D, Shackelford DB, Shaw RJ and Jones RG: Loss of the tumor suppressor LKB1 promotes metabolic reprogramming of cancer cells via HIF-1 $\alpha$. Proc Natl Acad Sci USA 111(7): 2554-2559, 2014.

14 Shen YA, Chen Y, Dao DQ, Mayoral SR, Wu L, Meijer D, Ullian EM, Chan JR and Lu QR: Phosphorylation of LKB1/PAR-4 establishes Schwann cell polarity to initiate and control myelin extent. Nat Commun 5: 4991, 2014.

$15 \mathrm{Li} \mathrm{N}$, Huang D, Lu N and Luo L: Role of the LKB1/AMPK pathway in tumor invasion and metastasis of cancer cells. Oncol Rep 34(6): 2821-2826, 2015. 
16 Ritho J, Arold ST and Yeh ET: A critical SUMO1 modification of LKB1 regulates AMPK activity during energy stress. Cell Rep 12(5): 734-742, 2015.

17 Jenne DE, Reimann H, Nezu J, Friedel W, Loff S, Jeschke R, Müller O, Back W and Zimmer M: Peutz-Jeghers syndrome is caused by mutations in a novel serine threonine kinase. Nat Genet 18(1): 38-43, 1998.

18 Korsse SE, Peppelenbosch MP and van Veelen W: Targeting LKB1 signaling in cancer. Biochim Biophys Acta 1835(2): 194210, 2013.

19 Shorning BY and Clarke AR: Energy sensing and cancer: LKB1 function and lessons learnt from Peutz-Jeghers syndrome. Semin Cell Dev Biol 52: 21-29, 2016.

20 Gurumurthy S, Hezel AF, Berger JH, Bosenberg MW and Bardeesy N: LKB1 deficiency sensitizes mice to carcinogeninduced tumorigenesis. Cancer Res 68: 55-63, 2008.

21 Wingo SN, Gallardo TD, Akbay EA, Liang MC, Contreras CM, Boren T, Shimamura T, Miller DS, Sharpless NE, Bardeesy N, Kwiatkowski DJ, Schorge JO, Wong KK and Castrillon DH: Somatic LKB1 mutations promote cervical cancer progression. PLoS One 4(4): e5137, 2009.

22 Nakada D, Saunders TL and Morrison SJ: Lkb1 regulates cell cycle and energy metabolism in haematopoietic stem cells. Nature 468: 653-658, 2010.

23 Gurumurthy S, Xie SZ, Alagesan B, Kim J, Yusuf RZ, Saez B, Tzatsos A, Ozsolak F, Milos P, Ferrari F, Park PJ, Shirihai OS, Scadden DT and Bardeesy N: The Lkb1 metabolic sensor maintains haematopoietic stem cell survival. Nature 468(7324): 659-663, 2010.

24 Gan B, Hu J, Jiang S, Liu Y, Sahin E, Zhuang L, FletcherSananikone E, Colla S, Wang YA, Chin L and Depinho RA: Lkb1 regulates quiescence and metabolic homeostasis of haematopoietic stem cells. Nature 468(7324): 701-704, 2010.

25 Green AS, Chapuis N, Maciel TT, Willems L, Lambert M, Arnoult C, Boyer O, Bardet V, Park S, Foretz M, Viollet B, Ifrah N, Dreyfus F, Hermine O, Moura IC, Lacombe C, Mayeux P, Bouscary $\mathrm{D}$ and Tamburini $\mathrm{J}$ : The LKB1/AMPK signaling pathway has tumor suppressor activity in acute myeloid leukemia through the repression of mTOR-dependent oncogenic mRNA translation. Blood 116(20): 4262-4273, 2010.

26 Grimaldi C, Chiarini F, Tabellini G, Ricci F, Tazzari PL, Battistelli M, Falcieri E, Bortul R, Melchionda F, Iacobucci I, Pagliaro P, Martinelli G, Pession A, Barata JT, McCubrey JA and Martelli AM: AMP-dependent kinase/mammalian target of rapamycin complex 1 signaling in T-cell acute lymphoblastic leukemia: therapeutic implications. Leukemia 26(1): 91-100, 2012.

27 Falini B, Mecucci C, Tiacci E, Alcalay M, Rosati R, Pasqualucci L, La Starza R, Diverio D, Colombo E, Santucci A, Bigerna B, Pacini R, Pucciarini A, Liso A, Vignetti M, Fazi P, Meani N, Pettirossi V, Saglio G, Mandelli F, Lo-Coco F, Pelicci PG, Martelli MF and GIMEMA Acute Leukemia Working Party: Cytoplasmic nucleophosmin in acute myelogenous leukemia with a normal karyotype. N Engl J Med 352(3): 254-266, 2005.

28 Kiyoi H, Naoe T, Nakano Y, Yokota S, Minami S, Miyawaki S, Asou N, Kuriyama K, Jinnai I, Shimazaki C, Akiyama H, Saito K, Oh H, Motoji T, Omoto E, Saito H, Ohno R and Ueda R: Prognostic implication of FLT3 and N-RAS gene mutations in acute myeloid leukemia. Blood 93(9): 3074-3080, 1999.

29 Spiekermann K, Bagrintseva K, Schoch C, Haferlach T, Hiddemann $\mathrm{W}$ and Schnittger S: A new and recurrent activating length mutation in exon 20 of the FLT3 gene in acute myeloid leukemia. Blood 100: 3423-3425, 2002.

30 Pabst T, Mueller BU, Zhang P, Radomska HS, Narravula S, Schnittger S, Behre G, Hiddemann W and Tenen DG: Dominantnegative mutations of CEBPA, encoding CCAAT/enhancer binding protein-alpha (C/EBPalpha), in acute myeloid leukemia. Nat Genet 27(3): 263-270, 2001.

31 Thol F, Weissinger EM, Krauter J, Wagner K, Damm F, Wichmann M, Göhring G, Schumann C, Bug G, Ottmann O, Hofmann WK, Schlegelberger B, Ganser A and Heuser M: IDHI mutations in patients with myelodysplastic syndromes are associated with an unfavorable prognosis. Haematologica 95(10): 1668-1674, 2010.

32 Onozato R, Kosaka T, Achiwa H, Kuwano H, Takahashi T, Yatabe $\mathrm{Y}$ and Mitsudomi T: $L K B 1$ gene mutations in Japanese lung cancer patients. Cancer Sci 98(11): 1747-1751, 2007.

33 Launonen V, Avizienyte E, Loukola A, Laiho P, Salovaara R, Järvinen H, Mecklin JP, Oku A, Shimane M, Kim HC, Kim JC, Nezu $J$ and Aaltonen LA: No evidence of Peutz-Jeghers syndrome gene $L K B 1$ involvement in left-sided colorectal carcinomas. Cancer Res 60(3): 546-548, 2000.

34 Amos CI, Keitheri-Cheteri MB, Sabripour M, Wei C, McGarrity TJ, Seldin MF, Nations L, Lynch PM, Fidder HH, Friedman E and Frazier ML: Genotype-phenotype correlations in PeutzJeghers syndrome. J Med Genet 41(5): 327-333, 2004.

35 McKnight SL: On getting there from here. Science 330: 13381339, 2010.

36 Paschka P, Schlenk RF, Gaidzik VI, Habdank M, Krönke J, Bullinger L, Späth D, Kayser S, Zucknick M, Götze K, Horst HA, Germing U, Döhner H and Döhner K: IDH1 and IDH2 mutations are frequent genetic alterations in acute myeloid leukemia and confer adverse prognosis in cytogenetically normal acute myeloid leukemia with NPM1 mutation without FLT3 internal tandem duplication. J Clin Oncol 28(22): 3636-3643, 2010.

37 Yamaguchi S, Iwanaga E, Tokunaga K, Nanri T, Shimomura T, Suzushima $\mathrm{H}$, Mitsuya $\mathrm{H}$ and Asou $\mathrm{N}$ : IDHI and IDH2 mutations confer an adverse effect in patients with acute myeloid leukemia lacking the NPM1 mutation. Eur J Haematol 92(6): 471-417, 2014.

38 Matsumoto S, Iwakawa R, Takahashi K, Kohno T, Nakanishi Y, Matsuno Y, Suzuki K, Nakamoto M, Shimizu E, Minna JD and Yokota J: Prevalence and specificity of $L K B 1$ genetic alterations in lung cancers. Oncogene 26(40): 5911-5918, 2007.

39 Koivunen JP, Kim J, Lee J, Rogers AM, Park JO, Zhao X, Naoki K, Okamoto I, Nakagawa K, Yeap BY, Meyerson M, Wong KK, Richards WG, Sugarbaker DJ, Johnson BE and Jänne PA: Mutations in the $L K B 1$ tumour suppressor are frequently detected in tumours from Caucasian but not Asian lung cancer patients. Br J Cancer 99(2): 245-252, 2008.

40 Jansen M, Ten Klooster JP, Offerhaus GJ and Clevers H: LKB1 and AMPK family signaling: the intimate link between cell polarity and energy metabolism. Physiol Rev 89(3): 777-798, 2009. 